\title{
DIAGNOSIS OF THE PULMONARY TUBERCULOSIS BY POLYMERASE CHAIN REACTION: A COMPARATIVE STUDY BETWEEN HIV-POSITIVE AND -NEGATIVE INDIVIDUALS
}

\author{
Rosemeri Maurici da Silva', Tairone Machado², Maria Luiza Bazzo ${ }^{3}$
}

${ }^{1}$ Programa de Mestrado em Ciências da Saúde, Universidade do Sul de Santa Catarina, Tubarão, SC, Brasil; ${ }^{2}$ Universidade do Sul de Santa Catarina, Tubarão, SC, Brasil; ${ }^{3}$ Departamento de Análises Clínicas, Universidade Federal de Santa Catarina, Florianópolis, SC, Brasil.

Submitted: December 12, 2010; Approved: January 16, 2012.

\begin{abstract}
This study was performed to assess the efficiency of polymerase chain reaction (PCR) directly from sputum for the diagnosis of pulmonary tuberculosis by comparison between HIV-positive and HIV-negative individuals. Sputum samples were collected from hospitalized patients admitted with a clinical diagnosis of pulmonary tuberculosis, and subjected to smear microscopy, culture on LJ medium and detection of $M$. tuberculosis by PCR. Sensitivity, specificity, and predictive values (positive and negative) were calculated using smear and/or culture at day 42 as the gold standard, by comparing the yield in HIV-positive and HIVnegative individuals. Regardless of serostatus, the technique's yield had 62\% sensitivity, $70 \%$ specificity, $79 \%$ positive predictive value, $50 \%$ negative predictive value, and $65 \%$ accuracy. HIV-negative had $64 \%$ sensitivity, $74 \%$ specificity, $75 \%$ positive predictive value, $63 \%$ negative predictive value, and $68 \%$ accuracy. HIV-positive had $59 \%$ sensitivity, $33 \%$ specificity, $87 \%$ positive predictive value, $10 \%$ negative predictive value, and 56\% accuracy. The PCR showed a higher yield in HIV-negative individuals compared to HIV-positive individuals.
\end{abstract}

Key words: Tuberculosis. HIV. PCR. Sputum.

The special program of the World Health Organization for research and training in tropical diseases expressed concern regarding the diagnosis and treatment of tuberculosis in developing countries, arguing that the primary impediment to controlling the disease lies on inadequate case detection. The pandemic of HIV, immunosuppression linked or not linked to this virus, and the worldwide increase of TB cases with $M$. tuberculosis drug resistant stress the need for better diagnostic tools. Although the initial diagnosis of mycobacterial disease is based on clinical data, the definitive diagnosis depends on laboratory isolation and identification of the microorganism (19).

Early diagnosis has a crucial role in TB control. However, the bacilloscopy has a low sensitivity in paucibacillary clinical samples and the culture in Löwenstein-Jensen medium is slow; besides, the laboratory results may take several weeks $(12,13)$.

\footnotetext{
*Corresponding Author. Mailing address: Rodovia Virgílio Várzea, 2236, Residencial Villa Vernazza, Apto 601, Bloco A, CEP 88032001, Florianópolis, SC.; E-mail: rosemaurici@hotmail.com
} 
The reversal of this scenario will require the development of new strategies to increase the quality and speed of TB diagnosing. The estimate for the next 20 years is that the increase in case detection will reduce the incidence by $41 \%$ and new treatment regimens will control the disease and reduce its transmission by up to $59 \%$. The combination of new diagnostic methods and new drugs may result in a decreased incidence of around $76 \%$ during this same period of time (22).

Detection of mycobacterial DNA directly from sputum by amplification of the $16 \mathrm{~S}$ rDNA gene allows the rapid identification of species (20). However, the amplification of this gene in sputum has proven challenging because it presents sensitivity values below those desired for diagnosis $(2,5,7)$.

This study was conducted to assess the yield of PCR directly from sputum, comparing the yielding capacity between HIV-positive and HIV-negative individuals.

Sputum samples were obtained from in-patients with a clinical diagnosis of TB, with a maximum of two days of treatment, admitted to a TB reference hospital, from January to November 2009, and processed within two hours after collection. Each sample was homogenized and separated into three parts: one for sputum smear microscopy according to Ziehl-Nielsen staining, one for DNA extraction and subsequent PCR detection, and the third part for the decontamination procedure by the Petroff method and culturing in LöwensteinJensen solid medium. Smear preparation, Ziehl-Nielsen staining and slide reading followed the recommendations outlined in the Manual of Tuberculosis Bacteriology (11).

DNA extraction from sputum was performed by alkaline lysis; all reagents had molecular biology grade purchased from Invitrogen $^{\circledR} \quad$ (Carlsbad, CA, USA) (17): sputum was resuspended in GET (50 mM glucose, $25 \mathrm{mM}$ Tris- $\mathrm{HCl}$, $\mathrm{pH} 8.0$ and $10 \mathrm{mM}$ of EDTA), followed by cell lysis solution $1 \%$ SDS, $0.2 \mathrm{M} \mathrm{NaOH}$. The $\mathrm{pH}$ was neutralized with a solution of $3 \mathrm{M}$ potassium acetate, $\mathrm{pH} 4.8$ to 5.0. Then, the sample was treated with proteinase $\mathrm{K} 20 \mathrm{mg} / \mathrm{ml}$. The extraction was performed with phenol/chloroform/isoamyl alcohol (25:24:1) and the
DNA was precipitated in ethanol in the presence of salt and resuspended in $20 \mu \mathrm{l}$ of $\mathrm{TE}(10 \mathrm{mM}$ Tris $\mathrm{pH} 7.4,1 \mathrm{mM}$ EDTA). Quality control of the DNA extracted and verification of inhibitors in PCR reaction were made with primers ZR-244 and F-285 that amplify a 350-bp fragment of $16 \mathrm{~S}$ rRNA conserved for eubacteria (16). Detection primers were obtained from the rDNA sequence corresponding to nucleotides of the 16S rRNA gene (7). Antisense primer MYC-264 (4) nucleotide 1638 to 1657 (3'TGCACACA GGCCACAAGGGA-5') and sense primer F-285 nucleotides 631 to 648 (5'-AGAGTTTG ATCCTGGCTCAG -3') amplified a fragment of $1027 \mathrm{bp}$. The PCR reaction was performed in a volume of $50 \mu$ containing dimethyl sulfoxide (DMSO) under the following conditions: $1.5 \mathrm{mM} \mathrm{MgCl}$, 1\% DMSO, $0.8 \mathrm{mM}$ dNTP (dATP, dCTP, dGTP, dTTP), 10 pmoles of each primer, $1 \mathrm{X}$ Taq polymerase buffer and $1.25 \mathrm{U}$ recombinant Taq polymerase (Invitrogen ${ }^{\circledR}$ Carlsbad, CA, USA) and $1 \mu \mathrm{l}$ of DNA template. Amplification condition used was $94^{\circ} \mathrm{C}$ for 1 minute, $60^{\circ} \mathrm{C}$ for 1 minute, $72^{\circ} \mathrm{C}$ for 1 minute in 35 cycles and a final cycle of $72^{\circ} \mathrm{C}$ for 10 minutes. PCR was performed in a PCR thermocycler Eppendorf $^{\circledR}$ brand, Mastercycler Personal model. The electrophoretic separation of DNA extracted and PCR products was performed with the application of $5 \mu$ of these materials with the addition of $1 \mu \mathrm{l}$ of $6 \mathrm{X}$ sample buffer (30\% glycerol, $0.25 \%$ Bromophenol blue, $0.25 \%$ xylene cyanol and $10 \% 10 \mathrm{X}$ TAE - 40 mM Tris-acetate/1 mM EDTA) in 1\% (w/v) agarose gel, in 1X TAE buffer at $200 \mathrm{~V}$ for ten minutes. Visualization was achieved by ethidium bromide staining $(1 \mu \mathrm{g} / \mathrm{ml})$. Gels were photographed under ultraviolet light at $320 \eta \mathrm{m}$ (HOEFER-MacroVue UV-20), using a gel photodocumentation system (DOC-PRINT ${ }^{\circledR}$ Biosystems). The size of fragments was estimated by comparison with the molecular size marker of $50 \mathrm{pb}$ (Invitrogen ${ }^{\circledR}$ Carlsbad, CA, USA). The pattern sample used as positive control of PCR amplification was DNA extracted from the BCG vaccine which contains attenuated bacillus Calmette-Guérin.

The samples were cultured after decontamination using 
the Petroff technique (11). The cultures that showed no bacterial growth up to 42 days were considered negative.

The PCR assay results were interpreted without knowledge of the results of the reference standard. PCR reactions were repeated if a false-negative result occurred.

The SPSS $16.0^{\circledR}$ software was used to calculate sensitivity, specificity, predictive values (positive and negative), taking the culture on the 42nd day as the gold standard.

The research project was submitted to and approved by the Ethics Committee in Human Research (CEPSH) of the University of Southern Santa Catarina.

Eighty-five patients were consecutively evaluated; mean age was 43.6 years $(\mathrm{SD} \pm 11.7) ; 69(81.2 \%)$ were male. With regard to ethnicity, $71(83.5 \%)$ were Caucasians. Of the participants, $60(70.6 \%)$ were HIV-negative and 25 (29.4\%) were HIV-positive.

Bacilloscopy and/or culture was positive in 55 (64.7\%) of the samples and negative in $30(35.3 \%)$. PCR was positive in $43(50.6 \%)$ of the samples and negative in $42(49.4 \%)$.

Table 1 shows the distribution of participants according to the bacilloscopy and/or culture, PCR and HIV seropositivity.

Table 2 shows the yield of PCR using the result of bacilloscopy and/or culture as the golden standard.

Table 1. Distribution of the participants according to the result of bacilloscopy and/or culture, PCR and HIV seropositivity.

\begin{tabular}{|c|c|c|c|c|}
\hline \multirow[t]{2}{*}{ Status } & \multirow[t]{2}{*}{ PCR } & \multicolumn{2}{|c|}{$\begin{array}{c}\text { Baciloscopy and/or Culture } \\
\text { n (\%) }\end{array}$} & \multirow[t]{2}{*}{ Total } \\
\hline & & + & - & \\
\hline \multirow{3}{*}{ HIV - Positive } & + & $13(52 \%)$ & $2(8 \%)$ & $15(60 \%)$ \\
\hline & - & $9(36 \%)$ & $1(4 \%)$ & $10(40 \%)$ \\
\hline & Total & $22(88 \%)$ & $3(12 \%)$ & $25(100 \%)$ \\
\hline \multirow{3}{*}{ HIV- Negative } & + & $21(35 \%)$ & $7(11,7 \%)$ & $28(46,7 \%)$ \\
\hline & - & $12(20 \%)$ & $20(33,3 \%)$ & $32(53,3 \%)$ \\
\hline & Total & $33(55 \%)$ & $27(45 \%)$ & $60(100 \%)$ \\
\hline \multirow{3}{*}{$\begin{array}{l}\text { Independent of } \\
\text { serostatus }\end{array}$} & + & $34(40 \%)$ & $9(10,6 \%)$ & $43(50,6 \%)$ \\
\hline & - & $21(24,7 \%)$ & $21(24,7 \%)$ & $42(49,4 \%)$ \\
\hline & Total & $55(64,7 \%)$ & $30(35,3 \%)$ & $85(100 \%)$ \\
\hline
\end{tabular}

Table 2. PCR yield compared to the golden standard.

\begin{tabular}{lccccc}
\hline \multirow{2}{*}{ Status } & \multicolumn{5}{c}{ Statistical measures (CI 95\%) } \\
\cline { 2 - 6 } & Sensitivity & Specificity & PPV & PPN & Accuracy \\
\hline \multirow{2}{*}{ HIV - Positive } & 59 & 33 & 87 & 10 & 56 \\
& $(39-80)$ & $(-20-86)$ & $(69-100)$ & $(-8-25)$ & $(37-75)$ \\
HIV- Negative & 64 & 74 & 75 & 63 & 68 \\
Independent of & $(47-80)$ & $(57-90)$ & $(59-91)$ & $(46-80)$ & $(57-80)$ \\
serostatus & 62 & 70 & 79 & 50 & 65 \\
\hline
\end{tabular}

Studies show that from colonies grown on LJ, PCR has $100 \%$ sensitivity in the amplification of the $16 \mathrm{~S}$ rDNA gene, while sputum sensitivity values range between $22 \%$ and $72.4 \%$; these values are always associated with the quality of sputum $(2,3)$. DNA extracted directly from sputum contains bacteria of the upper respiratory tract and mouth, fungi, leukocytes and other cells. However, a greater sensitivity of PCR through the culture could not explain the discrepancy in yield, whose values of specificity between HIV positive and independent of their serostatus, are $33 \%$ and $70 \%$, respectively. 
The intensity of amplification is different for each sample and seems not to be related to the number of bacilli found in bacilloscopy. Ievens and Goossens (8), in a meta-analysis article, stated that some authors ascribe the different results in different methodologies when using the same sample by unequal distribution of the mycobacteria present in sputum to the difficulty of perfect sample homogenization, mainly because mycobacteria appear to be heavily clustered in some samples, which makes their separation and an equal distribution in sputum very difficult. This characteristic has been observed by the authors, daily, in sputum smears that, despite being prepared after proper sputum homogenization, have mycobacteria grouped with irregular distribution in the slide.

PCR is an alternative method for diagnosis of pulmonary tuberculosis among HIV-positive and negative individuals, besides the culture and/or bacilloscopy, with the advantage of a rapid and simultaneous identification of $M$. tuberculosis, but the disadvantage of a higher cost. It is said that, although the PCR presents specificity and negative predictive value lower than desirable in samples of HIV-positive individuals, the technique can still be advantageous when compared with conventional methods for the rapid diagnosis of paucibacillary pulmonary tuberculosis. To date, there has been no other method more effective when the combination of conventional clinical, radiological and microbiological findings does not establish the diagnosis.

The PCR technique can reduce the diagnosis time and may increase the detection of mycobacteria in smear-negative TB. However, variations in procedures for in-house PCR could explain the wide variability of sensitivity and specificity reported in several studies. None of them present a comparison between HIV-positive and negative individuals (1, 5, 10, 18).

Other factors, such as the quantity of bacilli, can influence the performance of PCR. Wu et al. (23), using nested-PRA for the hsp65 gene, identified $100 \%$ of samples with $3+$ bacilli, $95 \%$ of samples with $2+$ bacilli, and only $53 \%$ of samples with
$1+$ or fewer bacilli. This could explain the lower yield in HIVpositive patients often shown in paucibacillary samples. Another possibility could be the presence of non-tuberculous mycobacteria in this specific group of patients, which reduces the yield.

Lima et al. (9) showed that the PCR, compared to other methods (bacilloscopy and culture), showed $77.5 \%$ sensitivity, slightly higher than that found in this study in HIV-negative individuals.

Querol et al. (15) report that more than 10,000 bacilli per milliliter of sputum are required to ensure smear-positive microscopy. The success of microscopy is highly variable (22 to 96 percent), although most authors classify it by 60 percent. In that study, the authors found PCR positivity in $97 \%$ of patients diagnosed with pulmonary tuberculosis.

With the outbreak of AIDS, it was clinically observed that the TB manifestations in these patients were not equal to those of HIV-negative patients. Furthermore, there is a greater number of infections caused by non-tuberculous mycobacteria, which grow in culture media, but are not amenable to isolation by PCR with specific primers for M. tuberculosis $(6,14)$. Contributing to the diagnostic difficulty, are the negativity of tuberculin test and sputum bacilloscopy. Sputum smears are negative in up to $40 \%$ of HIV patients with positive cultures for resistant acid-fast bacilli (21). The differences in clinical, radiological (with few cavity forms), and laboratory presentation of pulmonary tuberculosis in this group of patients may justify the difference in the yield of PCR for diagnosis of pulmonary tuberculosis, although specific studies correlating each of these factors with the yield of the technique should be performed.

\section{REFERENCES}

1. Assis, N.C.S.; Lopes, M.L.; Cardoso, N.C.; Costa, M.M.; Souza, C.O.; Lima, K.V.B. (2007). Diagnóstico molecular da tuberculose pulmonar. J. Bras. Patol. Med. Lab. 43 (1), 1-7.

2. Bazzo, M.L. (2006). Método de identificação e caracterização de 
micobactérias para uso em diagnóstico de rotina nos laboratórios de saúde e determinação da resistência. Minas Gerais, Brasil, 135p. (PhD. Thesis. Instituto de Ciências Biológicas. UFMG).

3. Bazzo, M.L.; Ferreira, L.A.P.; Silva, R.M.; Scheffer, M.; Chagas, M.; Severino, J.L.; Rovaris, D.B.; Nauck, R.; Ferreira, P.C.P. (2004). Relação entre a Qualidade de Amostras de Escarro e o Diagnóstico de Micobacterioses por PCR. Arq. Cat. Med. 33 (3), 23-27.

4. Boddinghaus, B.; Roggal, T.; Florhr, T.; Blocker, H.; Bottger, E.C. (1990). Detection and identification of mycobacteria by amplification of rRNA. J. Clin. Microbiol. 28 (8), 1751-1759.

5. Flores, L.L.; Pai, M.; Colfors, J.R.; Riley, L.W. (2005) In-house nucleic acid amplification tests for the detection of Mycobacterium tuberculosis in sputum species: meta-analysis and meta-regression. BMC. Microbiol. 5,55 .

6. Helbert, M.; Robinson, D.; Buchanan, D.; Hellyer, T.; McCarthy, M.; Brown, I.; Pinching A.J.; Mitchell, D.M. (1990). Mycobacterial infection in patients infected with the human immunodeficiency virus. Thorax. 45 (1), 45-48.

7. Hughes, M.S.; Skuce, R.A.; Beck, L.A.; Neill, S.D. (1993). Identification of mycobacteria from animals by restriction enzyme analysis and direct DNA cycle sequencing of polymerase chain reaction-amplified $16 \mathrm{~S}$ rRNA gene sequences. J. Clin. Microb. 31 (12), 3216-3222.

8. Ievens, M.; Goossens, H. (1997) Relevance of nucleic acid amplification techiques for diagnosis of respiratory tract infections in the clinical laboratory. Clin. Microbiol. Rev. 10 (2), 242-256.

9. Lima, S.S.S.; Clemente, W.T.; Palaci, M.; Rosa, R.V. (2008). Métodos convencionais e moleculares para o diagnóstico da tuberculose pulmonar: um estudo comparativo. J. Bras. Pneumol. 34 (12), 10561062.

10. Marchi, A.M.; Juttel, I.D.; Kawacubo, E.M.; Dalmarco, E.M.; Blatt, S.L.; Cordova, C.M.M. (2008). Evaluation of methods for detection and identification of Mycobacterium species in patients suspected of having pulmonary tuberculosis. Braz. J. Microbiol. 39, 613-618.

11. Ministério da Saúde. (2008). Manual Nacional de Vigilância Laboratorial da Tuberculose e Outras Micobactérias. Fundação Nacional de Saúde, Brasília.
12. Negi, S.S.; Khan, S.F.B.; Gupta, S.T.; Pasha, S.T.; Khare, S.; Lal. S. (2005). Comparison for the conventional diagnostic modalities, Bactec culture and polymerase chain reaction test for diagnosis of tuberculosis. Indian. J. Med. Microbiol. 23 (1), 29-33.

13. Neonakis, I.K.; Gitti, Z.; Kramboviits, E.; Spandidos, D.A. (2008). Molecular diagnostics tools in mycobacteriology. J. Microbiol. Methods. 75 (1), 1-11.

14. Pitchenik, A.E.; Rubinson, H.A. (1985) The radiographic appearance of tuberculosis in patients with the acquired immune deficiency syndrome (AIDS) and pre-AIDS. Am. Rev. Respir. Dis. 131 (3), 393-396.

15. Querol, J.M.; Farga, M.A.; Granda, D.; Garcia de Lomas, C.J. (1995). The utility of Polymerase Chain Reaction (PCR) in the diagnosis of pulmonary tuberculosis. Chest. 107 (6), 1631-1635.

16. Rogall, T.; Flohr, T.; Bottger, E.C. (1990). Differentiation of Mycobacterium species by direct sequencing of amplified DNA. J. Gen. Microb. 136 (9), 1915-1920.

17. Sambrook, J.; Russel, D.W. (2001). Molecular Cloning: A Laboratory Manual. Cold Spring Harbor Laboratory Press, New York.

18. Sarmiento, O.L.; Weigle, K.A.; Alexander, J.; Weber, D.J.; Miller, W.C. (2003). Assessment by meta-analyses of PCR for diagnosis of smearnegative pulmonary tuberculosis. J. Clin. Microbiol. 41 (7), 3233-3240.

19. Soini, H.; Musser, J.M. (2001). Molecular Diagnosis of Mycobacteria. Clin. Chemistry. 47 (5), 809-814.

20. Walerio-Aleixo, A.G.; Kroon, E.G.; Campos, M.A.S.; Margutti-Pinto, M.E.; Bonjardim, C.A.; Ferreira, P.C.P. (2000). Heteroduplex Mobility Assay for Rapid, sensitive and specific Detection of Mycobacteria. Diagn. Microbiol. Infect. Dis. 36 (4), 225-235.

21. Watson, J.M.; Gill, O.N. (1990) HIV infection and tuberculosis. BMJ. 300 (13), 63-65.

22. World Health Organization. (2008) Implementing the Stop TB strategy.A handbook for national tuberculosis control programmes. WHO/HTM/TB, Geneva.

23. Wu, T.L.; Chia, J.H.; Kuo, A.J.; Su, L.H.; Wu, T.S.; Lai, H.S. (2008). Rapid identification of Mycobacteria from smear positive sputum samples by Nested PCR-Restriction fragment length polymorphism analysis. J. Clin. Microbiol. 46 (11), 3591-3594.

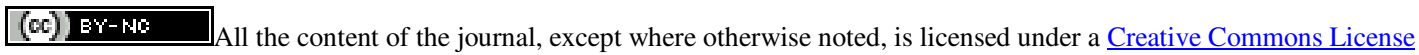

